\title{
Perspectives
}

\section{Toward the Development of Intercultural Communicative Competence: Theoretical and Pedagogical Implications for Japanese English Teachers}

\author{
Keiko Komiya Samimy \\ Chiho Kobayashi \\ The Ohio State University
}

Although CLT (Communicative Language Teaching) was introduced into Japanese English education in the mid-1980s under the initiative of the Monbukagakusho (the National Ministry of Education, Science, and Culture of Japan), the implementation of CLT has been challenging for Japanese English teachers. This article explores possible sources for the difficulties that CLT has caused in Japan. It examines factors such as Japanese sociocultural, political, and educational contexts that have significant influence on curricular innovation. This article further argues that the underlying assumptions of CLT that are based on the native-speaker competence model are not compatible with the contexts of Japanese English education because these assumptions include native-speaker competence as a primary goal of second language acquisition. Recognizing the current status of English as an international language, the authors propose an alternative model based on the notion of intercultural communicative competence (Alptekin, 2002) and discuss how the model of intercultural communicative competence can be applied to Japanese English education.

1980 年代半ばから、文部科学省の指導の下で日本の英語教育にコミュニカティブ・ アプローチが導入されているが、コミニュカティブ・アプローチの実践は日本の英語教師 にとって依然として困難な試みである。本論はコミュニカティブ・アプローチが日本にも たらしている問題の要因を探るために、カリキュラムの改変に影響を及ぼす日本の社会文 化的、政治的、教育的状況を検討する。さらに、母国語話者のコミュニケーション能力を 前提とするコミュニカティブ・アプローチは、ネイティブのコミュニケーション能力を第 二外国語習得の主な目標とする点で日本の英語教育に適さないと論じる。最後に、現在英 語が果たしている国際語としての役割を認識した上で、異文化コニュニケーション能力の 概念に基づくモデルを新たに提案し、このモデルがどのように日本の英語教育に応用でき るのかを検討する。

JALT Journal, Vol. 26, No. 2, November, 2004 


\section{Introduction}

Japanese English education has gone through notable curricular innovations and reforms since the mid-1980s. Currently the development of the learners' overall communicative competence in English is emphasized more than grammatical competence only. In 1989, for example, the Monbukagakusho (the national Ministry of Education, Science, and Culture of Japan) introduced a revised set of guidelines or The Course of Study for English at both primary and secondary schools, which clearly reiterates the importance of Communicative Language Teaching (CLT hereinafter) activities in the classroom. In addition, since 1985, the Monbukagakusho has been actively recruiting native speakers of English to assist Japanese teachers of English under the project called the Japan Exchange and Teaching Program (JET). The reported purpose of the JET program is "to deepen mutual international understanding through cooperation between native speakers of English or AETs (Assistant English Teachers) and the local citizens in Japan as well as through the AETs helping teaching English to the general public and to returnee students from oversees countries" (Koike \& Tanaka, 1995, p. 20). Or to put it more simply, the rationale behind the JET program is "to bring the L2 community into the classroom" (Wada, 2002, p. 220).

Furthermore, the Monbukagakusho has been sponsoring one-month domestic training programs and six-month and one-year study abroad programs for Japanese teachers of English. The objectives of these programs are (a) to improve teachers' communicative ability in English, (b) to introduce innovative teaching methods, and (c) to improve participants' teaching skills especially in using these innovative methods (Wada, 2002). It is reported that in 1998, 136 teachers participated in overseas programs and 600 more took part in domestic programs (Wada, 2002).

Despite the enormous efforts that the Monbukagakusho has been putting into the reform of Japanese English education, research findings seem to suggest that the reform has not been very impressive thus far (Lamie, 2001; Law, 1995; Wada, 2002) and continues to be confusing and frustrating for many Japanese English teachers.

The purposes of this paper are threefold: a) to review some of the reported obstacles to implementing CLT in Japan, b) to critically examine the tacit assumptions behind the CLT approach, and c) to propose an alternative pedagogical model which is based on the notion of intercultural communicative competence (Alptekin, 2002). 


\section{Theoretical Background}

\section{CLT}

Since Hymes introduced it in the mid-1960s, the term "communicative competence" has been defined by scholars in many different ways (Canale \& Swain, 1980). Among these definitions, practitioners and researchers frequently draw on those of Canale and Swain (1980), Canale (1983), and Savignon (1983, 2002).

Canale and Swain (1980) propose three components of communicative competence: grammatical, sociolinguistic, and strategic. Canale (1983) extends the model to include four components: grammatical, sociolinguistic, discourse, and strategic competence. Grammatical competence includes knowledge of vocabulary and of rules of morphology, syntax, semantics, and phonology. Sociolinguistic competence is knowledge of the rules of use that denote the ways in which utterances are produced appropriately in a given sociocultural context depending on factors such as the roles of the participants, the purposes of the interaction, and the norms of the interaction. Discourse competence is concerned with knowledge of how to combine forms and meanings to achieve unified spoken or written texts. Finally, strategic competence refers to knowledge of verbal or nonverbal communication strategies that may be called on during communication breakdown, due to performance variables or insufficient competence. The four components of communicative competence interact with one another in communication.

Drawing on Canale and Swain (1980) and Canale (1983), Savignon $(1983,2002)$ proposes an "inverted pyramid" classroom model of communicative competence that consists of four components: grammatical, sociocultural, discourse, and strategic competence. Grammatical, sociocultural, and discourse competence increase as overall communicative competence increases. On the other hand, although it is present at all levels of proficiency, the relative importance of strategic competence decreases as grammatical, sociocultural, and discourse competence increase. All the components interact to produce an increase in overall communicative competence. Although the definition of each component is generally the same as that of Canale and Swain (1980) and Canale (1983), Savignon's definition of sociocultural competence includes not only knowledge of L2 culture but also intercultural awareness, defined as "a general empathy and openness toward other cultures" (Savignon, 2002, p. 10). Savignon asserts that the inclusion of intercultural awareness 
in sociocultural competence is necessary for the teaching and learning of English, given the status of English as an international language. When English is used as a means of communication across different nations or cultures, the success of communication hinges on the "negotiation of meaning" and the "willingness to suspend judgment and take into consideration the possibility of cultural differences" among those involved (p. 10) rather than the adoption of native English linguistic and sociolinguistic norms. Sociocultural or sociolinguistic competence in the international context involves more than just knowing the culture of English-speaking countries.

Thus, the goal of CLT is to assist the learner in achieving the ability to integrate skillfully the four components of communicative competence and to convey meaning successfully in a socially appropriate manner. Due to the lack of clear-cut content specifications, there are a variety of approaches in CLT that share only the "general common objective, namely, to prepare learners for real-life communication rather than emphasizing structural accuracy" (Celce-Murcia, Dörnyei, \& Thurrell, 1997, p. 143). Although CLT has been interpreted in different ways, the tenets of CLT commonly include a focus on meaning, a focus on communicative functions, the use of authentic tasks, the use of authentic materials, learner-centered perspectives, an emphasis on the needs and interests of the learner, the use of group or pair activities, and the importance of a secure, nonthreatening atmosphere (Savignon, 1983; Li, 1998).

While CLT is currently promoted as the dominant methodology in foreign/second language teaching, it has been reported that teachers have difficulties with implementing CLT in their classrooms. Celce-Murcia et al. (1997), for example, argue that problems intrinsic to CLT, such as the lack of appropriate assessment instruments and the insufficient treatment of linguistic competence, are related to the difficulties. To be implemented successfully, a curricular innovation must be accompanied by corresponding changes in evaluation; however, teachers find it difficult to evaluate students' ability to communicate. The instruments to evaluate students' communicative competence holistically, such as oral interviews, compositions, and portfolios, are more time-consuming and less reliable than traditional paper-and-pencil, discrete-point examinations. Moreover, holistic assessments cannot be easily operationalized with the existing school cultures, which stress values such as objectivity and efficiency. The neglect of linguistic competence by many CLT proponents is another impediment to the implementation of CLT (CelceMurcia et al., 1997). They focus on communicative functions and notions 
over linguistic forms, arguing that the latter are learned incidentally while focusing on meaning. In many classrooms, CLT contradicts existing methods, such as the Grammar-Translation method, which emphasize grammatical accuracy. Furthermore, the limitations of focusing on meaning exclusively are increasingly clear. In the past decades, scholars have claimed that "making learners aware of structural regularities and formal properties of the target language will greatly increase the rate of language attainment" by using different theoretical frameworks, such as "consciousness raising," "input enhancement," "language awareness," and "focus on form" (Celce-Murcia et al., 1997, p. 145). These theoretical frameworks emphasize that attention should be given to target structures in communicative activities.

In addition to the common problems with CLT discussed above, CLT causes unique problems when it is "imported" into EFL (English as a foreign language) contexts without careful consideration of contextual factors. The next section deals with the challenges specific to implementing CLT in EFL contexts.

\section{CLT in EFL Contexts}

It is not possible to claim a pedagogical universality for the concept of communicative competence without careful consideration of the sociocultural, educational, and political milieu (Kachru, 1992; Savignon, 2002) since the roles and the functions of English vary from one country to another. However, there is a hegemonic assumption (Phillipson, 1992) that if something works in the Inner Circle (e.g. in countries such as the U.S. and the U.K., see Kachru, 1992 for further discussion), it should work equally well in the Expanding Circle (e.g. Japan, China, Korea). Yet, this assumption is quite misleading for English language teaching (ELT) professionals in the Expanding Circle due to the contextual disparities between the Inner and the Expanding Circle countries. In his theoretical framework for understanding curricular innovation, Markee (1997), for example, refers to Kennedy's (1988) model, which suggests that "multiple sociocultural systems potentially interact to constrain classroom innovation ... and in this model, cultural values are the most powerful shapers of participants' behaviors, followed by political conventions, administrative practices and so on" (p. 55, emphasis added).

Since English continues to be recognized as a lingua franca, whose ownership does not exclusively belong to native speakers (see Kachru, 1992; McKay, 2002; Phillipson, 1992; Widdowson, 1994), it is particularly 
important to consider the sociocultural, political, and educational variables involved in the local use of English when discussing innovations and implementations of new teaching methodologies in EFL contexts. The first contextual factor that needs to be examined is the distinction between teaching EFL and ESL (English as a second language). Although English has long been taught as a foreign language in Japan, necessary pedagogical as well as practical considerations have not received adequate attention from the Monbukagakusho or from those who have been involved in Japanese English curriculum innovations.

\section{Revisiting ESL and EFL Distinctions}

While we have to be careful not to oversimplify the distinctions between ESL and EFL or view them as being somewhat dichotomous, some differentiation between the two constructs is necessary for a number of reasons. Strevens (1992), for example, argues why the ESL and EFL distinctions matter. He states, "it [the distinction] makes a very considerable difference, when it comes to the teaching and learning of English...it affects the extent of the learner's prior familiarity with English, it affects the learner's expectations of success, and it affects both the average level of attainment reached by most learners and the ultimate norms or goals for success which learners and teachers set themselves" (pp. 36-37, emphasis added).

In EFL contexts, English is used in educational situations where instruction in other subjects is not normally given in English (Prater, 1991); thus, English is typically taught as a foreign language inside the classroom and as one of the school subjects in the school curriculum. In general, most EFL students have little opportunity to have contact with English in their everyday lives outside of the classroom except through activities such as browsing the Internet (Eun, 2001).

In ESL contexts, on the other hand, English is learned or taught as a partial or entire medium of instruction for other subjects. ESL students thus receive much if not most of their education through the medium of English and have sufficient opportunities to be exposed to English both inside and outside the classroom. In other words, ESL students have both a supportive environment and an urgent need to use English outside of the classroom. Therefore, one of the advantages of the ESL situation is that the target language community is immediately available for students to study, practice, and test their English. However, these advantages are not readily available in EFL contexts. 
In addition to the lack of access to English and the relative unavailability of L2 input outside the classroom, there are other factors that should differentiate CLT implementation in Japan from implementation in ESL contexts. Examples include learner factors (their needs and motivation), teacher factors (nonnative speakers of English), and socialeducational factors (entrance examinations and large class sizes). We will first focus on learner and teacher components that are often neglected in curriculum innovations. As Schubert (1986) states, "The literature of the curriculum field has too long neglected to give attention to both teachers and students as creators and transformers of curriculum" (p. 422).

\section{Japanese Learner Factors and CLT}

The first factor involves the learners themselves. Law (1995) criticizes The Course of Study (1989) by the Monbukagakusho stating, "[While] welcoming the broad intent of these reforms we must note ... unresolved issues. First, within the Guidelines for Foreign Languages, the specific description of the course contents for particular years and subjects often seems to use concepts and terminology drawn from communicative theory in a mechanical and formalistic way, with little regard for the likely range of real communicative needs among Japanese children" (p. 220, emphasis added). What are the real communicative needs among Japanese school-age children? Unlike learners in ESL contexts, Japanese learners do not have an immediate necessity nor pressure to master communicative skills in English.

For Japanese learners, in particular, middle school and high school students, the study of English is closely associated with "juken eigo," or "English for entrance examinations," which emphasizes grammar, vocabulary, and reading comprehension. In addition, there is clear evidence that as the date for university entrance exams draws nearer, students expect their teachers to focus on "juken eigo" (Hildebrant \& Giles, 1983) since the entrance exams will affect the future success of their lives. According to Kodaira (1996), 77\% of students in a private academic high school thought that passing university entrance exams was the reason for studying English.

Similarly, a study of 876 Japanese EFL teachers by Gorsuch (2000) corroborates the backwash effect of university entrance exams on Japanese English education and highlights the powerful impact that such tests have on educators. She states, "the most striking, although not surprising, finding was the centrality of university entrance examinations in 
the educational culture. By "centrality," I mean that the exams seemed strongly intertwined with teachers' perceptions of their local school cultures and their classroom teaching experiences..." (p. 699). In short, as long as the entrance exams continue to occupy a powerful determining role in Japanese education, Japanese school-age children, particularly those who are faced with immediate pressures to pass entrance examinations, will inevitably focus on "juken eigo" rather than communicative English.

This does not mean, however, that Japanese students do not have other reasons for studying English. Although they do not have immediate communicative needs, they need to be prepared for global communication in the future. The ability to communicate in English is becoming important for them as global contact increases. Citing Crystal (1997), McKay (2002) reports on the dominance of English in various areas, including international organizations, motion pictures, popular culture, publications, electronic communications, and education. To negotiate various academic, political, economic, and cultural issues with people around the world, many of the students will be required to use English in "highly sophisticated communication," both face-to-face and on-line (Warschauer, 2000, p. 158), although they may not need the whole range of communicative competence. These global interactions will include both those with native speakers and those with other nonnative speakers. A pedagogical model which promotes learners' English skills for global communication will be discussed later in this paper.

\section{Japanese Teacher Factors and CLT}

The second factor that deserves our close attention is the situations concerning the Japanese teachers of English. Unlike the teachers in most ESL settings, English instructors in EFL settings are predominantly nonnative speakers of English. Generally, it is reported that being a nonnative speaker of English affects a teacher's level of communicative confidence (Braine, 1999; Savignon, 2002), which hence, discourages educators from using communicative English in their classes. Japanese English teachers are not an exception. In CLT classrooms, Japanese teachers often teach communicative English either by asking AETs to do it or by relying on more traditional ways of teaching (Sato, 2002). While team-teaching with AETs is supposed to encourage more communicative activities in the classroom, their presence can be not only intimidating but also threatening to some Japanese English teachers 
who lack communicative confidence (Savignon, 2002). In addition, the division of labor between native and nonnative teachers of English can only reinforce a stereotypical image; that is, nonnative teachers of English cannot become role models for students when it comes to achieving communicative confidence and competence in English. Furthermore, as Law (1995) asserts, "unless and until we see a greater number of nativespeaker teachers involved in teaching reading skills, for example, and of nonnative speaker teachers seeing it as a primary duty to teach oral skills, it will be difficult to convince students that all are engaged in the same enterprise, and that communication skills are not marginal aspects of language learning" (p. 222, emphasis added).

On the other hand, nonnative EFL teachers, who share linguistic and cultural backgrounds with their students, have their strengths. Widdowson (1994) argues that nonnative English teachers are in a better position than native teachers to teach "authentic" English to their students. This is because "authentic" English for students is not the native variety of English spoken in contexts that are unfamiliar to them, but the English that is appropriate for their sociocultural situations, and nonnative teachers have a better understanding of the students' reality. Nonnative teachers can be excellent facilitators to make learning relevant to students and engage students in communicative experiences by drawing on their L2 and local experience and addressing their unique needs (Cook, 1999).

\section{Socioeducational Factors in Japan}

Socioeducational factors can also impede the implementation of CLT in Japanese schools. The effect of entrance examinations on current English education has been already mentioned. It has a major impact on the learners, as well as on the teachers. Unless the entrance examination format changes in the future, there will be a washback effect on the existing English curriculum, which will continue to make "teach to the test" a pervasive pedagogical approach in Japan.

Additionally, there may be other cultural mismatches between theoretical underpinnings of CLT and the Japanese culture of learning. For example, Ellis (1996) argues that Western values embedded in CLT, such as the relative importance of process as opposed to content and the emphasis on meaning over form, make it unsuitable for Asian learners and teachers. Miller (1995) reports on the difference between Western and Japanese communication styles perceived by Japanese university students, although their attitudes toward Western styles were not always 
negative. The Japanese students perceived that while their American teacher's class was nontraditional and/or communicative, their Japanese teachers' classes were traditional and teacher centered. The American teacher focused on "developing oral skills, "creating a lively, enjoyable atmosphere," "encouraging active participation," and "occasionally overlooking mistakes" (p. 41). On the other hand, the Japanese teachers mainly gave lectures focusing on grammatical accuracy. Likewise, Matsuura, Chiba, and Hildebrandt (2001) report that, whereas instructors at Japanese universities preferred more innovative pedagogy such as a learner-centered approach, integrated skills, and a focus on fluency, students generally preferred more traditional approaches such as a teacher-centered approach, translation, and focusing on pronunciation. Although the cultural dichotomy, which promotes the idea of Otherness (Kubota, 1999), should not be overstressed, these cultural differences may partially explain the difficulties with implementing CLT in Japan.

Furthermore, since the curriculum in Japan is centralized, there is pressure on the teachers to conform to the guidelines dictated by the Monbukagakusho. In other words, despite the lip service that we pay about teachers being critical agents for adopting any educational reforms (Markee, 1997), in reality, classroom teachers' voices are often either neglected or ignored, particularly in Japanese society where the Monbukagakusho's "manner of reform in foreign language education has been described as top-down, with input being generated by highlevel bureaucrats and university consultants" (Gorsuch, 2000, p. 678).

It should be recognized then, that although the above-mentioned contextual factors are not comprehensive by any means, Japanese English teachers and policy makers need to approach "imported" teaching methodologies from the Inner Circle, such as CLT, with critical awareness and caution. Otherwise, Japanese English teachers will continue to "interpret" and/or "mediate" CLT to harmonize with their immediate needs in their teaching contexts, that is, preparing their students for university entrance examinations. As Gorsuch (2000) argues, political statements that "divorce content and instruction," such as The Course of Study, tend to sustain existing practices (p. 677). Unless The Course of Study reflects classroom teachers' realities and specifies how they can integrate the educational innovations into their contexts, they will continue to "subsume the document into the prevailing culture of university entrance exam preparation" (p. 701). 
Toward an Alternative Model of Communicative Language Teaching

As mentioned above, contextual variables such as sociocultural, educational, learner, and teacher factors continue to pose enormous challenges to Japanese English teachers in their attempt to implement CLT. We would argue that the basic assumptions of CLT are not in concert with the contextual situations of Japanese English education. Sridhar and Sridhar (1992), for example, point out the incompatibility of the underlying assumptions of many SLA theories for English learners living outside of the Inner Circle countries. Some of the assumptions include:

1. The goal of second language acquisition (SLA) is to acquire native-like competence in the target language (not only in terms of pronunciation and grammatical norms but also in the range of speech acts, styles, and register differentiation);

2. Input available to the learner is extensive and intensive enough to permit acquisition of native-like proficiency in the target language;

3. The learner should be able to perform the same range of functions in the target language as a monolingual speaker of the target language; and

4. The ideal motivation for learning the target language should be integrative and entails "admiration for native speakers of the target language and a desire to become a member of their culture" (p. 94).

The examination of the tacit assumptions of SLA theories is critical here since they inform the methodologies of language teaching such as CLT. Given that the underlying assumptions are not consistent with EFL contexts, it is not surprising that CLT has posed so many challenges for ELT professionals in countries included in the Expanding Circle, such as Japan. However, we would argue that these challenges can be overcome by incorporating the notion of English as an international language.

Smith (1976), who coined the term "international language," notes that "an international language is one which is used by people of different nations to communicate with one another" (p. 38) and identifies features of English as an international language:

1. Its learners do not need to internalize the cultural norms of native speakers of that language; 
2. The ownership of it has become "de-nationalized"; and

3. The educational goal of learning it is to enable learners to communicate their ideas and culture to others.

Taking into account the features of English as an international language, Alptekin (2002) challenges the appropriateness of CLT for ELT. He asserts: "with its standardized native speaker norms, the model is found to be utopian, unrealistic, and constraining in relation to English as an international language" (p. 57, emphasis added). Alptekin first argues that the notion of communicative competence that assumes a native speaker as a norm is as utopian as the notion of the idealized native speakerlistener, which is a nonexistent abstraction and a linguistic myth. He also argues that using a native speaker as a model does not recognize other linguistic and cultural variations. Secondly, Alptekin points out a changing ownership of English in the world. It is unrealistic, he asserts, that the native speaker model is used as the only legitimate and appropriate model, as the number of English users among nonnative speakers may well exceed the number of its native speakers. Finally, Alptekin asserts that the native speaker model of communicative competence stifles teacher and learner autonomy, particularly in EFL contexts, as long as they have to look up to native speakers as the source of authentic English. In order for learners and teachers to practice their autonomy, then, "[authentic language] needs to be localized within a particular discourse community" (p. 61).

In his intercultural communicative competence model, Alptekin (2002, p. 63) recommends the following five criteria to be taken into account:

1. Successful bilinguals with intercultural insights and knowledge should serve as pedagogic models for English as an International Language (EIL) rather than monolingual native speakers;

2. Intercultural communicative competence should be developed among EIL learners by equipping them with linguistic and cultural behavior which will enable them to communicate effectively with others, and also by equipping them with an awareness of differences, and with strategies for coping with such differences (Hyde, 1998);

3. EIL pedagogy should be one of global appropriacy and local appropriation in that it should prepare learners "to 
be both global and local speakers of English and to feel at home in both international and national cultures" (Kramsch \& Sullivan, 1996, p. 211);

4. Instructional materials and activities should involve local and international contexts that are familiar and relevant to language learners' lives; and

5. Instructional materials and activities should have suitable discourse samples pertaining to native and nonnative speaker interactions, as well as to nonnative and nonnative speaker interactions. Discourse displaying usage produced exclusively by native speakers should be kept to a minimum as it is chiefly irrelevant for many learners in terms of potential use in authentic settings (Widdowson, 1998).

How can Alptekin's model be applied to the Japanese English education? In the following section, the pedagogical implications are discussed.

\section{Pedagogical Implications}

If Alptekin's intercultural communicative competence model were to be incorporated into the existing Japanese English educational system, first, Japan's goals and norms would need to be revisited and examined from the perspective of English as an international language. As his first criterion indicates, the monolingual native speaker model needs to be replaced by the bilingual model where the teacher can relate to the students in both English and Japanese. Such a teacher would become a role model for the students by demonstrating linguistic as well as cultural behavior, which is appropriate in intercultural communication. The bilingual model should also emphasize the importance of mutual comprehensibility and intelligibility rather than native speaker norms and goals.

Secondly, instruction on grammar should remain an important part of the existing curriculum. Implementation of a purely communicative syllabus may not be feasible given the Japanese contextual factors discussed earlier (e.g. entrance examination, large class size, limitations of teachers' English proficiency). Rather, integration of structural and communicative syllabi may be theoretically and practically sound. Yalden (1983), for example, proposes a proportional approach in which "structural content is provided in increasingly smaller proportions 
relative to instruction based on increasingly larger units of discourse as overall language proficiency increases" (Krahnke, 1987, p. 88). Through this approach, the learners would receive both grammatical content and communicative content.

Thirdly, while there is a push toward the use of authentic materials along with CLT, McKay (2002) stresses the use of materials that include the learners' culture, the target culture, and international culture. She asserts that "the materials should be used in such a way that students are encouraged to reflect on their own culture in relation to others, thus helping to establish a sphere of interculturality" (p. 100). This would also be useful.

Finally, teaching methodologies and approaches that suit EFL contexts may be different from the ones employed in ESL contexts as the teachers in the EFL settings predominantly share the same first language as their students. While an "English only" approach may be appropriate and necessary in the ESL context, Japanese teachers need to use the two languages wisely and proportionately according to the learners' proficiency levels.

\section{Conclusion}

In summary, the existing model of communicative competence or CLT which is based on native-speaker norms is not adequate nor feasible for Japanese English education due to sociocultural and educational factors such as limited access to English, learners' restricted communication needs, nonnative teachers, a different culture of learning, and the dominance of university entrance examinations. Japanese English education should embrace CLT in a culturally sensitive and appropriate way, yet maintain its own contextual autonomy. Hence, we argue that a paradigm shift needs to occur with an emphasis toward intercultural communicative competence in Japanese English education. Such a paradigm shift will not only present a more realistic and feasible pedagogical model but also will assist students in developing communication skills required for global interactions. 
Keiko K. Samimy is Associate Professor in Foreign and Second Language Education at The Ohio State University. Her research interests include World Englishes and teaching English as an international language. She has taught English both in Japan and in the U.S.

Chiho Kobayashi is a Ph.D. candidate in Foreign and Second language Education at The Ohio State University. She is interested in L2 vocabulary acquisition and English as an international language.

\section{References}

Alptekin, C. (2002). Towards intercultural communicative competence in ELT. ELT Journal, 56(1), 57-64.

Braine, G. (1999). Non-native educators in English language teaching. Mahwah, NJ: Lawrence Erlbaum Associates.

Canale, M.(1983). From communicative competence to communicative pedagogy. In J. C. Richards \& R. W. Schmidt (Eds.), Language and communication (pp. 2-27). London: Longman.

Canale, M., \& Swain, M. (1980). Theoretical bases of communicative approaches to second language teaching and testing. Applied Linguistics, 1, 1-47.

Celce-Murcia, M., Dornyei, Z., \& Thurrell, S. (1997). Direct approaches in L2 instruction: A turning point in communicative language teaching? TESOL Quarterly, 31(1), 141-152.

Cook, V. (1999). Going beyond the native speaker in language teaching. TESOL Quarterly, 33(2), 185-209.

Crystal, D. (1997). English as a global language. Cambridge: Cambridge University Press.

Ellis, G. (1996). How culturally appropriate is the communicative approach? ELT Journal, 50(3), 213-128.

Eun, S. (2001). Contextual autonomy in EFL classrooms: A critical review of English teaching methods in South Korea. Unpublished doctoral dissertation, Ohio State University, Columbus, $\mathrm{OH}$.

Gorsuch, G. (2000). EFL educational policies and educational cultures: Influences on teachers' approval of communicative activities. TESOL Quarterly, 34(4), 675-709.

Hildebrant, N., \& Giles, H. (1983). The Japanese as subordinate language group: Ethnolinguistic identity theory in EFL context. Anthropological Linguistics, 25, 436-466.

Hyde, M. (1998). Intercultural competence. Modern English Teacher, 7(2), 7-11.

Kachru, B. (1992). World Englishes: Approaches, issues, and resources. Language Teaching, 25, 1-14. 
Kennedy, C. (1988). Evaluation of the management of change in ELT projects. Applied Linguistics, 9(4), 163-170.

Kodaira, F. (1996). Why not the "Japanese way"?: The traditional approach of learning English as a foreign language at secondary schools in Japan. Unpublished master's thesis, Columbia Teacher's College, Tokyo.

Koike, I., \& Tanaka, H. (1995). English in foreign language education policy in Japan: Toward the twenty-first century. World Englishes, 14(1), 13-25.

Krahnke, K. (1987). Approaches to syllabus design for foreign language teaching. Englewood Cliffs, NJ: Prentice-Hall.

Kramsch, C., \& Sullivan, P. (1996). Appropriate pedagogy. ELT Journal, 50(3), 199-212.

Kubota, R. (1999). Japanese culture constructed by discourses: Implications for applied linguistics research and ELT. TESOL Quarterly, 33(1), 9-36.

Lamie, J. (2001). Understanding change: The impact of in-service training on teachers of English in Japan. Huntington, NY: Nova Science.

Law, G. (1995). Ideologies of English education in Japan. JALT Journal, 17(2), 213-224.

Li, D. (1998). "It's always more difficult than you plan and imagine": Teachers' perceived difficulties in introducing the communicative approach in South Korea. TESOL Quarterly, 32(4), 677-703.

Markee, M. (1997). Managing curricular innovation. Cambridge: Cambridge University Press.

Matsuura, H., Chiba, R., \& Hildebrandt, P. (2001). Beliefs about learning and teaching communicative English in Japan. JALT Journal, 23(1), 69-89.

McKay, S. (2002). Teaching English as an international language. Oxford: Oxford University Press.

Miller, T. (1995). Japanese learners' reactions to communicative English lessons. JALT Journal, 17(1):31-53.

Ministry of Education, Science, and Culture. (1989). Commentary on the senior high school course guidelines: Foreign Languages (English). Tokyo: Author.

Phillipson, R. (1992). Linguistic imperialism. Oxford: Oxford University Press.

Prater, C.H. (1991). Cornerstones of method and names of the profession. In M. Celce-Murcia (Ed.), Teaching English as a second or foreign language. Boston: Heinle \& Heinle Publishers.

Sato, K. (2002). Practical understandings of CLT and teacher development. In S. Savignon (Ed.), Interpreting communicative language teaching (pp. 41-81). New Haven, CT: Yale University Press.

Savignon, S. (1983). Communicative competence: Theory and classroom practice. Reading, MA: Addison-Wesley.

Savignon, S. (2002). Interpreting communicative language teaching. New Haven, CT: Yale University Press. 
Schubert, W. H. (1986). Curriculum: Perspective, paradigm, and possibility. New York: Macmillan.

Smith, L. (1976). English as an international auxiliary language. RELC Journal, $7(2), 38-43$.

Sridhar, K. K., \& Sridhar, S. N. (1992). Bridging the paradigm gap: Second-language acquisition theory and indigenized varieties of English. In B. Kachru (Ed.), The other tongue: English across cultures (pp. 91-107). Urbana: University of Illinois Press.

Strevens, P. (1992). English as an international language: Directions in the 1990s. In B. Kachru (Ed.), The other tongue: English across cultures (pp. 27-47). Urbana: University of Illinois Press.

Wada, M. (2002). Teacher education for curricular innovation in Japan. In S. J. Savignon (Ed.), Interpreting communicative language teaching (pp. 31-40). New Haven, CT: Yale University Press.

Warschauer, M. (2000). The changing global economy and the future of English teaching. TESOL Quarterly, 34(3), 511-535.

Widdowson, H. G. (1994). The ownership of English. TESOL Quarterly, 28, 377388.

Widdowson, H. G. (1998). Context, community, and authentic language. TESOL Quarterly, 32(4), 705-716.

Yalden, J. (1983). The communicative syllabus: Evolution, design, and implementation. Oxford: Pergamon Press.

(Received August 1, 2003; accepted March 7, 2004) 